\title{
MODELOS DEL MUNDO MODERNO: HACIA UN CONSENSO DE IMÁGENES EN EL CINE DE LATINOAMÉRICA
}

\author{
Sebastião Guilherme Albano *
}

RESUMEN: Mediante la categoría de consenso de imágenes, el autor reflexiona sobre una fase de la industria fílmica de Latinoamérica. Para ello se contrastan los modelos adoptados por Argentina, Brasil y México al constituir sus respectivas industrias culturales, los cuales revelan sus maneras de integrar la Modernidad. Al considerar los filmes producidos en el periodo y la historia de algunas de sus instituciones modernas, el estudio subraya cómo la cultura, la economía y la política son partes de un mismo sistema de civilización.

Palabras Clave: Latinoamérica, Industria fílmica, Consenso de imágenes, Modernidad.

ABSTRACT: The article focuses on Latin American film industry. By analyzing the category of images of consensus, the author contrasts how Argentina, Brazil, and Mexico have integrated Modernity into their respective industrial-cultural models. In considering the history of modern institutions, the author underscores how culture, economics, and politics are part of the same system.

KEY WORDS: Latin America, Film Industry, Consensus of images, Modernity.

Este estudio describe algunos de los procesos por los que pasó la producción de cine en tres países de Latinoamérica, a saber, Argentina, Brasil y México, que son responsables del 89\% de las películas realizadas en la región. ${ }^{1}$ Aquí se da por hecho que el cine es, entre otras cosas, un soporte para determinado tipo de representación y de simbolización que encierra una lógica industrial compleja en sus modelos de construcción de sentido. Por

* Universidade Federal do Rio Grande do Norte (UFRN) (tiaoalbano@unb.br,zoroastros@ hotmail.com y sgac@ufrnet.br.)

${ }^{1}$ Octavio Getino, Cine y televisión en América Latina. Producción y mercado, Santiago de Chile, LOM ediciones/Ediciones Ciccus, 1998, p. 50. 
lo mismo, esos rasgos de origen orientan la creación de imágenes fílmicas hacia la sugerencia de los consensos que mantiene la sociedad moderna, algo señalado aquí en películas realizadas en la primera mitad del siglo xx. Los marcos generales de los regímenes semióticos de la modernidad, tales como el advenimiento del Estado nacional, el desarrollo de instancias capitalistas de relaciones económicas y la burocratización de la convivencia social, van a observarse como condicionantes de la imaginación creadora. ${ }^{2}$

En América Latina, la inscripción de enunciados diversos en unos cuantos discursos institucionalizados es auspiciada por el limitado número de actores sociales legitimados.

Esto se puede verificar por el hecho de que los avatares de su historia oficial se han proyectado en el perfil de muchas de sus realizaciones fílmicas, tanto en los procesos de producción de las cintas como en el orden diegético. ${ }^{3}$ Podría ser que ese nexo de proposiciones históricas y políticas elaboradas por pocos grupos, se debiera a pocos factores, de orígenes y con corolarios profusos.

Por ejemplo, desde el siglo XIX la escasez de algunas habilidades que propiciaron el ejercicio de la racionalidad occidental, especialmente el déficit en la alfabetización, primordial para la competencia en materia de contenidos temáticos y formas discursivas, fue decisiva para que en la región penetraran las propuestas más estables de la Modernidad europea sin que hubiera, en primera instancia, una revisión consciente de las mismas. Esa aprehensión se basó en una observación y operó un consecuente comentario que tendía a replicar las elaboraciones realizadas en los países centrales (Francia, Gran Bretaña y Estados Unidos). ${ }^{4}$ En el caso del cine, en muchas

2 Aquí régimen semiótico quiere decir algo análogo a un campo de significación.

${ }^{3}$ Emilio García Riera, Historia del cine mexicano, México, Secretaría de Educación Pública, 1985, pp. 128,129, 191-173 y 197, informa que en 1931, por ejemplo, 27\% de los filmes producidos en el país trataban de temas históricos. En 1943, el porcentaje subió a 47\%. El promedio en la actualidad es de cerca de 10\% . En el caso brasileño, el libro de Jean-Claude Bernadet y Alcides Freire Ramos, Cinema e história do Brasil, São Paulo, Contexto, 1994 [1988], los autores discurren sobre la incidencia casi ostensiva de la historia nacional en la cinematografía del país.

${ }^{4}$ Sobre ese carácter epigonal de la producción de cultura en Latinoamérica, más bien, sobre esa sensación de mal estar por la discusión sobre nuestra ineptitud para formular discursos ori- 
ocasiones, esa posición reiteró posiciones miserabilistas, a veces grotescas y kitsch, que, en verdad, demostraron una especie de ansiedad de la influencia y connotaron la injerencia ostensiva de esos temas en nuestra agenda. Cuando no, como en los casos de Fernando de Fuentes en México y de Mário Peixoto en Brasil, revelaba miembros talentosos de las élites criollas.

El cine regional tuvo, hasta los decenios de 1950 y 1960, dos claras instancias de inspiración, una de vertiente norteamericana y otra europea. Para la descripción de los esquemas generales reproducidos por el cine de Argentina, Brasil y México usaré la categoría de imágenes de consenso o de imaginación consensuada. La opción por esas naciones se justifica por su estadio más avanzado de industrialización e, inclusive, de occidentalización, si las comparamos con los demás países de América Latina, en que el cine tuvo una producción episódica y desarticulada, y solamente participaron de los procesos de exhibición y distribución de filmes, aun como subsidiarios de las majors foráneas. Los tres, por otro lado, fueron marcados por una relación un poco más intrincada con las directrices metropolitanas, y establecieron a lo largo de su historia una especie de dialéctica entre términos como dependencia/independencia, originalidad/emulación, provincianismo/ cosmopolitismo, dicotomías formuladas por sus mismas élites y conforme a sus intereses.

Evoco la categoría de imágenes de consenso o de imaginación consensuada para connotar un movimiento de textualización que reúne el sesgo poético/retórico a las prácticas sociales que privilegian un grupo de figuras representativas (imaginario nacionalista, iconografía regional, figuras del autoritarismo, expresión mimética de las ciencias sociales). Imagen de consenso evoca una suerte de cooptación de cierta racionalidad en detrimento de otra por intermedio de la producción de imágenes, en nuestro caso imágenes de cine, ejemplificadas por las películas aludidas más adelante.

ginales en los soportes modernos de expresión (novela y film, por ejemplo), Roberto Schwarz tiene un texto que describe esa preocupación regional de las ciencias humanas y sociales, que se llama “Nacional por subtração”, Que horas são?, São Paulo, Companhia das Letras, 1997 [1987]. 
En este estudio, sin embargo, imagen de consenso se suma a la definición de imaginario del teórico brasileño Teixeira Coelho, para quien, en relación a las políticas culturales, "na forma de programas de ação cultural concretos, a questão central que a imaginação simbólica propõe é a que consiste em levantar as constelações de imagens prevalentes, ou quase constantes, com o objetivo de traçar as linhas de forças culturais de um determinado grupo social". 5

Para emprender la descripción de la trayectoria que el cine recorrió en los tres países voy a partir de reflexiones sobre el ascenso de algunos patrones de la Modernidad y la especificidad de sus argumentos en la historia local. Es pertinente empezar con la posición de Jürgen Habermas, para quien la Modernidad es un proyecto incompleto, ${ }^{6}$ y acoplarlo con Octavio Paz, quien comenta sobre los avatares epistemológicos emprendidos en las sociedades modernas: "lo moderno es una tradición. Una tradición hecha de interrupciones y en la que cada interrupción es un comienzo.”7 Lo moderno, por tanto, implica la tradición de la ruptura porque es una constante suya, la ruptura de la tradición.

En ese sentido, no deja de ser curioso que en los debates académicos sobre la posmodernidad o la modernidad tardía, esa idea de proyecto incompleto o de integración de las diferencias, que supone la presencia en el espacio de la modernidad de regiones no europeas, encuentra resonancia y lastre epistemológico. No obstante, lo que sobresale en el debate son la estabilidad y persistencia discursivas de lo moderno. En nuestro estudio

${ }^{5}$ José Teixeira Coelho Neto, Dicionário de política cultural, São Paulo, Iluminuras, 1999 [1997], pp. 211 y 212. Las cursivas son mías. Hice también la traducción libre que sigue: “Como programa de acción cultural concreto, la principal cuestión que la imaginación simbólica plantea es la de señalar las constelaciones de imágenes dominantes, o más o menos constantes, a fin de delinear las fuerzas culturales de un determinado grupo social”.

6 Jürgen Habermas, "Modernidad, un proyecto incompleto", uso la edición de Nicolás Casullo [ed.], El debate modernidad-posmodernidad, Buenos Aires, Punto Sur, 1989. El texto del filósofo alemán apareció por primera vez en 1980.

${ }^{7}$ Octavio Paz, Los hijos del limo, Barcelona, Seix Barral, 1987 [1986], p. 17. Cabe resaltar que la discusión en la cual Octavio Paz se inscribe corresponde a la idea de una modernidad común a Occidente, en que América Latina se inserta inevitablemente. 
sobre la industria del cine en la región esa manutención puede ser asociada a la imaginación de consenso promovida por el cine de corte industrial de la primera mitad del siglo Xx.

En América Latina la modernización política y económica, legitimada por la cuestión cultural, no dejó de ser una discusión de las élites y su gran tema era el cómo encuadrar a una población tan heterogénea en su órbita de interés, por cuanto las soluciones autoritarias fueron las más buscadas. Esa situación puede ser caracterizada por el hecho de que hasta hace poco hubo instituciones de control cultural estricto (partidos como el PRI en México y su DPPR, la Subsecretaría de Información y Prensa de la Presidencia de la República, en el gobierno de Perón, o el Departamento de Imprensa e Propaganda (DIP) de Getúlio Vargas en Brasil), con el claro afán de adoctrinar a las masas de inmigrantes, iletrados, indígenas o ex esclavos negros que componían la mayoría de la población en casi todos los países y se resistieron a asimilar el sistema de los estados nacionales y sus corolarios, es decir, algunos de los regímenes semióticos de la modernidad.

Debido a tales versiones de nuestro ethos, para José Joaquín Brunner debemos pensar dos veces antes de afirmar que realmente pasamos por una fase de Modernidad, toda vez que nunca cumplimos de hecho con los requisitos que la caracterizan. ${ }^{8}$ Como contrapunto, Jesús Martín Barbero aboga por la tesis de que hubo un aprendizaje escandaloso de los contenidos modernos, inculcados no por políticas culturales, sino por la acción de los medios de comunicación, especialmente los audiovisuales, entre no-

${ }^{8}$ El comentario de José Joaquín Brunner es de América Latina, cultura y modernidad, México, Grijalbo/Conaculta, 1992, p. 121: "Existe una tesis que sostiene que la modernidad se impuso en América Latina como un artificio, una mentira[... . Según esta tesis, para ser modernos nos faltó casi todo: reforma religiosa, revolución industrial, burocratización en serio del Estado, empresarios shumpeterianos y la difusión de una ética individualista, procesos que recién producidos hubieran hecho posible, después, la aparición en estas latitudes del ciudadano adquisitivo que produce, consume y vota conforme a un cálculo racional de medios y fines.” Walter Mignolo tiene reflexiones semejantes sobre nuestra incorporación a ese sistema-mundo de la modernidad en Historias locales/diseños globales. Colonialidad, conocimientos y pensamiento fronterizo, trad. de Juan María Madariaga y Cristina Vega Solís, Madrid, Akal, 2003. 
sotros un instrumento de consenso ideológico tan o más importante que la escuela.

Por más escandaloso que suene, es un hecho cultural que las mayorías en América Latina se están incorporando a, y apropiándose de, la modernidad sin dejar su cultura oral, esto es no de la mano del libro sino desde los géneros y las narrativas, los lenguajes y los saberes, de la industria y la experiencia audiovisual. [...] Lo que entonces necesitamos pensar es la profunda compenetración —la complicidad y complejidad de relaciones — que hoy se produce en América Latina entre la oralidad que perdura como experiencia cultural primaria de las mayorías y la visualidad tecnológica, esa forma de "oralidad secundaria” que tejen y organizan las gramáticas tecnoperceptivas de la radio y el cine, del vídeo y la televisión. Pues esa complicidad entre oralidad y visualidad no remite a los exotismos de un analfabetismo tercermundista $\left[\ldots . .{ }^{9}\right.$

Siguiendo la misma línea de interpretación, Beatriz Sarlo, Carlos Monsiváis, Flora Süssekind, Jesús Martín Barbero, José Luis Romero y Renato Ortiz, ${ }^{10}$ entre otros, concluyen que, además, en América Latina, a partir de las independencias, constituirse como nación significó la asunción de un proyecto de modernización capitalista que observara la creación de un mercado interno en que circularan productos y símbolos. Derivado de la dinámica de la historia se percibe que el ascenso del paradigma capitalista liberal norteamericano, promotor de la empresa privada y del Estado con atri-

${ }^{9}$ Jesús Martín Barbero y Germán Rey, Los ejercicios del ver, hegemonía audiovisual y ficción televisiva, Barcelona, Gedisa, 1999, p. 34.

${ }^{10}$ Sería pertinente ver las conclusiones de los estudios de esos investigadores, puesto que proporcionan una noción de nuestra modernidad a partir de los contenidos expuestos por los media. Sin embargo, voy a citar nada más los libros de algunos de ellos en que se encuentran tales reflexiones. Ángel Rama, La ciudad letrada, Hanover, Ediciones del norte, 1984; Beatriz Sarlo, La imaginación técnica: sueños modernos de la cultura argentina, Buenos Aires, Nueva Visión, 1992; Carlos Monsiváis, "Los héroes y el post-heroísmo: América Latina y la búsqueda de ejemplos”, artículo inédito tomado de Edmundo Paz-Soldán y Debra A. Castillo, "Beyond the Lettered City”, en Latin American Literature and Mass Media (editado por Edmundo PazSoldán e Debra A. Castillo), Nueva York, Garland Publishing, 2001. Renato Ortiz, A moderna tradição brasileira, São Paulo, Brasiliense, 1995 [1988]. 
buciones más reguladoras que emprendedoras, se impuso lentamente en el siglo xx como un contrapunto a la centralización europea que hasta ese momento había servido de modelo al sistema político y cultural de América Latina. El desarrollo de los cines nacionales en Argentina, Brasil y México obedece a esa dinámica.

La pujanza económica de Estados Unidos, su creciente peso en las decisiones mundiales y el carácter popular de su cultura — este último un fenómeno típico de las Américas - llevaron a que sus prácticas sociales fueran objeto de admiración en otras sociedades, desplazando la influencia del estilo parisino por el californiano. Entre esos valores, creo que el más influyente fue el que promovió la consolidación de una esfera pública en que nuevos agentes participaran, o parecían participar, auxiliando de esa manera a la constitución de una sociedad que representaba el mito de la igualdad de derechos mediante esquemas de identidad que se explicaban por la clave de la ciudadanía de mercado.

Quizá por ello la categoría de cultura popular, que en los proyectos latinoamericanos estaba situada generalmente en el ámbito del folclor, fue sustituida por una nueva escala, cuya clasificación implicaba distintos grados de urbanización y era formulada por las industrias culturales y la necesaria ascensión de las figuras del empresario y del profesional liberal, que promovían la representación del pueblo. Esa nueva modalidad fue denominada por Ángel Rama como cultura democratizada, no democrática. ${ }^{11}$

Al ser el cine un medio de expresión cuyos orígenes y límites representativos son la sociedad moderna e industrial, se debe emprender la descripción de la producción fílmica en América Latina de acuerdo a los parámetros de su proceso de industrialización o su inserción en el mundo capitalista. ${ }^{12}$

11 Ángel Rama, Las máscaras democráticas del modernismo, Montevideo, Fundación Ángel Rama, 1985, p. 39. No parece necesario ensanchar las referencias sobre el debate en torno de los conceptos de cultura popular e industria cultural, en vista de la perentoria distinción que hicieron Max Horckheimer y Theodore Adorno.

12 Jesús Martín Barbero, De los medios a las mediaciones. Comunicación, cultura y hegemonía, México, Gustavo Gilli, 1991, pp.157 y 158: "Más aún que en la prensa será en el cine donde se haga ostensible la universalidad de la gramática de producción de cultura masiva elaborada 
En este estudio, trataremos de realizarlo mediante la correlación entre la industria del cine en los tres países antes mencionados y la naturalización de los argumentos del mundo moderno, delineado por Europa y Norteamérica. Ese método nos llevará a establecer la propensión a los consensos imagéticos, es decir, a la creación de figuras fílmicas que estén en armonía con los parámetros metropolitanos.

Trataremos solamente del periodo en que las cinematografías de Argentina, Brasil y México siguieron, predominantemente, el modelo de industrialización norteamericano, es decir, el llamado cine de género, muy presente hasta el decenio de 1950 entre nosotros. Cabe mencionar que entre 1960 y 1970, debido a la noción de imperialismo cultural, al desprestigio del capitalismo entre las naciones del llamado Tercer Mundo y a la enorme cantidad de cineastas latinoamericanos, cerca de 150, que estudiaron en el Institut des Hautes Études Cinématographiques, de París, y en el Centro Sperimentale Cinematografia, de Roma, hubo una tendencia a privilegiar y adaptar a las condiciones locales los movimientos del neorrealismo y de la nouvelle vague, es decir, se pasó a un modelo de cine de autor. Entre 1970 y 1980, aunque las industrias siguieron con el apoyo oficial, la calidad del cine de género en el periodo fue bastante relativa, con énfasis en las comedias eróticas. ${ }^{13}$ En los primeros años del cine, entre 1896 y 1930, el predominio norteamericano no estaba asegurado, operaban Alemania, Italia y Francia como modelos también.

De hecho, la hegemonía norteamericana en los esquemas de la imaginación occidental se consolidó por su intervención bélica en la Primera Guerra Mundial, cuando fue convocado a salvar el viejo continente, contienda de la cual salió bastante débil. Los países de Europa que contaban

por los norteamericanos. Justo en el cine, ese ‘arte nómada y plebeyo’ cuyo lugar de nacimiento es la barraca de feria y el music hall. [...] El público mayoritario del cine provenía de las clases populares, y en la Norteamérica de ese tiempo, de las más populares de todas que eran las desarraigadas masas de inmigrantes. La pasión que esas masas sintieron por el cine tuvo su anclaje más profundo en la secreta irrigación de identidad que allí se producía.”

13 Paulo Antonio Paranaguá, Tradición y modernidad en el cine de América Latina, Madrid, FCE, 2003, pp. 244-263. 
con industrias fílmicas desarrolladas vieron la producción de filmes y la exportación para América Latina reducirse drásticamente, hecho que se acentuó aún más cuando la participación de Estados Unidos se volvió crucial en la derrota de los nazi-fascistas en la Segunda Guerra.

En el periodo de la Segunda Guerra en América Latina se estimuló la política de buena vecindad de Franklin Delano Roosevelt y entre 1935 y 1945 se promovió, por primera vez, la constitución de una industria fílmica regional. México contó con ayuda norteamericana y especialmente de la compañía RKO, y llegó a competir en exhibición con los extranjeros. CLASA, en 1934, y los Estudios Churubusco, 1945, construyeron 180 mil metros cuadrados de estudios profesionales. La presencia de Orson Welles en Brasil en 1942 marca el estilo del acercamiento con el país.

La competencia entre Europa y Estados Unidos está presente desde la introducción del cine en América Latina, a finales del siglo XIX. Basta recordar las sucesivas presentaciones de los aparatos de Edison y Lumière, amén de otras marcas. La Belle Époque de la primera década del siglo xx tuvo un claro predominio europeo. [...] Solamente con el alargamiento y la complejidad de la narración empieza a formarse un espectador en el sentido equivalente al que concurría al teatro. Pero aun el más perspicaz ¿vería entre Cabiria (Giovane Pastrone, Italia, 1914) e Intolerancia (Intolerance, David W. Griffith, Estados Unidos, 1916) la competencia entre dos industrias en ciernes? [...] Fue después de la Segunda Guerra Mundial que la competencia cobró fuerza, con la instalación de representaciones de compañías norteamericanas en América Latina, que le fueran conquistando el terreno a las empresas europeas momentáneamente fuera de combate por el conflicto bélico. [...] Si la Belle Époque fue europeizante, los Roaring Twenties fueron años de americanización, entonces como hoy para muchos sinónimo de modernización. $^{14}$

De hecho, la proporción entre filmes nacionales y norteamericanos en exhibición en México durante los decenios que abarcaron los antecedentes

${ }^{14}$ Ibid., pp. 89, 90 y 481. Se va a notar alguna discrepancia entre los números de Paranaguá y de Jorge Ayala Blanco, expuestos más adelante, pero ambos establecen la hegemonía norteamericana. 
y los años inmediatamente posteriores a la Segunda Guerra Mundial, demuestra la constancia de la supremacía del vecino del Norte, situación que permanece y que se expandió por casi todo el planeta. Entre 1930 y 1939 en México se estrenan 2388 filmes norteamericanos (en inglés, 76\% del total); 199 filmes mexicanos (6.9\%); 91 filmes norteamericanos en castellano (2.9\%); 31 españoles (1\%); 19 argentinos (0.6\%). Entre 1940 y 1949, la participación es de 2864 filmes norteamericanos (en inglés), 69.2\%; 629 filmes mexicanos (15.1\%); 222 filmes argentinos (5.4\%); 58 españoles (1.44\%), y 3 filmes norteamericanos en español. En Brasil en 1940 cerca del $86 \%$ de las películas exhibidas eran de origen estadounidense y en Argentina $66 \%{ }^{15}$

Si es cierto que en los tres países los resultados de los esfuerzos por desarrollar una industria del cine puede ser buen material para ilustrar la escalada de la imaginación de consenso, el caso mexicano es excepcionalmente revelador, aunque el argentino y el brasileño también señalen la anuencia de las élites nacionales con el modelo norteamericano de producción industrial de películas. ${ }^{16}$ Desde los años de 1930 Argentina contaba con cierta infraestructura de producción y distribución de filmes, inclusive con alguna ascendencia sobre los mercados próximos en Sudamérica, pero el episódico apoyo de Estados Unidos a la producción mexicana fue determinante para que este país sustituyera a los argentinos. Mientras en 1939 Argentina produjo 50 películas y México 38, en 1943 México produjo 70 y Argentina $34 .{ }^{17}$

En Argentina, Brasil y México los consensos de la imaginación en el cine se dieron en las intersecciones entre lo público y lo privado. El caso más

15 Jorge Ayala Blanco y María Luisa Amador, Cartelera cinematográfica 1930-1939 y 1940-1949, México, UNAM, 1982.

${ }^{16}$ Getino, op. cit., p. 50, da cifras que señalan que el apoyo norteamericano pudo llevar a la casi consolidación de una industria del filme en México, aunque no se deba descartar los apoyos internos y de países europeos. Entre 1930 y 1996 fueron producidos 11 mil filmes en América Latina, siendo cinco mil mexicanos, 2.5 mil brasileños y dos mil argentinos, totalizando $89 \%$ de las películas rodadas en la región.

17 Jorge Schnitman, Film Industries in Latin America Dependency and Development, Noorwood, Nueva Jersey, Ablex Publishing Corporation, 1984, pp. 116 y 117. 
notable fue el mexicano, puesto que los procesos que llevaron a la estabilidad política del país en el siglo xx pasaron por una constante sublimación de la Revolución por un grupo de liberales que aplacaron su ímpetu de cambio radical en una institución política que, con diferentes nombres, se conservó más de 70 años en el poder. En Brasil y en Argentina, la naturalización de la ideología del populismo nacionalista es quizá la clave para aclarar esa relación, en que las élites que componían el Estado y que debían legitimarse de alguna manera, lo hacían con los medios discursivos más incisivos. Lo curioso de ello es que la industria cultural, que tiene un carácter desterritorializado por excelencia, sirvió, en los tres países, para empadronar las señales más ostensivas de la nacionalidad, que aclimataron la tecnología transnacional a sus necesidades, actualizando los proyectos románticos del siglo XIX.

Un escenario más complejo se presenta cuando se observa que muchos de los nuevos formadores de opinión en América Latina son extranjeros, europeos, especialmente en Argentina, Brasil y Uruguay, y se vuelven empresarios de la industria cultural aquí. Algunos inclusive fueron directores de películas extrañamente patrióticas, como el francés Carlos Mongrand en México, o Mario Gallo y Atilio Lipizzi en Argentina, y Líbero Luxardo y Vittorio Capellaro en Brasil. Además, sus aliados criollos en general representaban una especie de extensión sesgada de las oligarquías terratenientes. De esa combinación (nuevos medios de comunicación, masas urbanas desarraigadas, pactos entre élites de diversa índole: económica, intelectual, política y racial) nace la nueva generación de actores políticos y culturales en la región, que tal vez estén exentos de apego a las tradiciones locales, puesto que muchos son liberales internacionalistas o sencillamente liberales en lo que concierne a economía, al tiempo en que incorporan un patriotismo utilitario y retórico, haciendo uso de esas bases para emprender un proyecto de modernización. Esa dinámica es la que lleva a críticos como Carlos Monsiváis a desconfiar de la aplicación nacionalista de los medios:

En las primeras décadas del siglo, las grandes batallas del nacionalismo como ideología de masas se libran contra las amenazas externas y contra la desunión, 
y para esto se recurre por razones de propaganda y por vez primera a las culturas populares. El nacionalismo no es sólo vestimenta oficial del Estado; sobre todas las cosas es identidad rápida que cohesiona los fragmentos de la vida cotidiana de las mayorías compensándolas en algo por la falta de derechos democráticos. ${ }^{18}$

De hecho, los inmigrantes fueron los principales promotores de la industria audiovisual en la región y con ellos hubo un cambio de modelos en lo que concierne a las producciones culturales y un avance a los consensos modernos. En Río de Janeiro, por ejemplo, la creación de la Cinelândia, un espacio en el centro de la ciudad fundado por el gallego Francisco Serrador Carbonell, instaura el nuevo modelo cultural: el cine norteamericano. Desde el nombre del lugar, plagado de cines y teatros al estilo de la Broadway, hasta las cintas en exhibición, la injerencia del american way of life en las mentalidades cariocas es inequívoca. Lo mismo ocurre en las calles de Corrientes y Lavalle en Buenos Aires, en donde Max Glücksmann era el emprendedor más destacado en la tarea de modernizar a la americana una ciudad que había sido construida bajo los patrones arquitectónicos de París. ${ }^{19}$

Si el cine también puede ser considerado en América Latina, como en Europa, el resultado de la Revolución Industrial en el ámbito del entretenimiento y de los discursos representativos, hasta más o menos 1907 éramos más consumidores que creadores de imágenes y, como fue dicho, las primeras vistas aquí fueron hechas por extranjeros, Gabriel Veyre en México y Paschoal y Affonso Segreto en Brasil lo ilustran. Las primeras películas na-

${ }^{18}$ Carlos Monsiváis, "Cultura urbana y creación intelectual. El caso mexicano”, en Pablo González Casanova [coord.], Cultura y creación intelectual en América Latina, México, Siglo XXI, 1984, pp. 24-41, el autor argumenta que las intenciones nacionalistas de las élites políticas resultan en procesos de desnacionalización, toda vez que la manera en que los contenidos de la cultura local están inscritos en la lógica de los medios promueve una desmaterialización de las tradiciones culturales de determinadas comunidades.

${ }^{19}$ Cabe remarcar que al tiempo en que el cine se volvió algo más que un aparato científico en Europa, a partir de 1900, la cantidad de inmigrantes en las capitales del Cono Sur era muy significativo. La mitad de los habitantes de Montevideo era extranjera, mientras en São Paulo cerca de 30\% de la población lo era. Pero el caso argentino parece no tener parangón en el mundo, ya que en 1914 contaba con más de 30\% de extranjeros entre sus ciudadanos. 
cionales fueron, además, documentales y pequeños reportajes, y solamente se incursionó en el filme de argumento a partir de la Primera Guerra Mundial, aunque antes algunas puestas en escena teatrales y novelas fueran transpuestas al cine en México (Don Juan Tenorio, 1899, Salvador Toscano), en Brasil, (Os Guaranys, 1908, Antonio Leal), y en Argentina, (La batalla de Maipú, 1913, de Mario Gallo).

En todos esos filmes, así como en las películas documentales de la Revolución mexicana, por ejemplo, el intento redundaba, aun sin quererlo, en la promoción de una iconografía nacional, siguiendo inconscientemente los aludidos proyectos románticos. Lo refuerza el hecho de que los filmes históricos y las adaptaciones literarias fueron parte importante de la cinematografía latinoamericana hasta el decenio de 1920 y serían fracción importante de la producción posterior. ${ }^{20}$

Como lo estima Jesús Martín Barbero, haciendo un paralelo con la función pedagógica que la novela en el siglo XIX tuvo en Latinoamérica, proyectando casi subliminalmente la imaginación de la oligarquía y la incipiente clase media internacionalista a las masas incultas, también el cine y la radio desde siempre mostraron "su capacidad de hacerse voceros de la interpelación que desde el populismo convertía a las masas en pueblo y al pueblo en Nación. [...] El cine en algunos países y la radio en casi todos proporcionaron a las gentes de las diferentes regiones y provincias una primera vivencia cotidiana de la Nación."21 De esa manera, el formato de sociedad moderna en la que tratábamos de inscribirnos desde las independencias quedaba legitimado por un producto cultural propio y no exótico.

Los productos de la cultura institucionalizada como la novela y el filme operaban en favor de una unidad simbólica de las naciones. En Brasil el periodo silente dio espacio a una regionalización de la producción, algo que connotaba las dimensiones geográficas del país y la natural existencia de

${ }^{20}$ Como dije antes, Emilio García Riera, en Historia del cine... y Jean-Claude Bernadet, en Cinema e história... hicieron estudios que atestiguan el alto porcentaje de películas latinoamericanas cuyo tema es la historia nacional. En México esa situación también se reproduce pero habría que contabilizarse con más cuidado para confirmar la información de García Riera.

${ }^{21}$ Barbero, op. cit., pp. 178 y 179. 
algunas divergencias entre los signos que circulaban por las diversas partes. Sin embargo, en poco tiempo se estableció una maniobra de selección de un regionalismo oficial que acabó proporcionando un sustrato de reconocimiento a la población de todo el país. Ese proceso fue definitivo en la novela, por ejemplo, en que los autores del norte del país, región con economía en declive, emergieron como grandes voceros de las miserias nacionales, y el ser nacionalista significaba, en los años de 1930 y 1940, reportarse a la iconografía nordestina.

El caso del cine fue algo diverso, debido principalmente al carácter económico que esta actividad encierra, al movilizar una variada cadena productiva. Alex Viany en Introdução ao cinema brasileiro recuerda que hubo ciclos regionales de producción de cine en Campinas, en el sudeste del país, en Recife, en el noreste, y en Cataguases, centro-sur, lugares más o menos distantes de los centros políticos, económicos y culturales, las ciudades de Río de Janeiro y São Paulo. ${ }^{22}$ Pero en breve la actividad se concentraría en esos estados.

Ese periodo estableció la tendencia general que seguiría el cine y la producción cultural institucionalizada en América Latina durante casi todo el siglo xx. La disyuntiva entre campo y ciudad, provincianismo y cosmopolitismo son series temáticas que solicitan valores de gran apreciación visual (en general relacionados con el folclor) y emocional (melodrama, nacionalismo, cristianismo), por lo que se volverían materia prima de gran parte de las cintas producidas en la región durante ese periodo y el posterior. Dan cuenta de ello los sainetes camperos y los musicales citadinos que tenían los gauchos o el tango como conductor de la trama en la cinematografía argentina (como los dirigidos por José Agustín el Negro Ferreyra, El organito de la tarde, 1926 y Muñequitas porteñas, 1931). Lo mismo los melodramas rancheros, muchos de ellas verdaderas críticas a la violencia de la Revolución (Allá en el rancho Grande, 1936, Fernando de Fuentes), toleradas y después fomentadas por presentar un modelo de mundo armónico buscado por los liberales que emergían. Y también lo demuestran las

${ }^{22}$ Alex Viany, Introdução ao cinema brasileiro, Río de Janeiro, Revan, 1993, pp. 25-32. 
chanchadas brasileñas, comedias urbanas que promovían la idea de sensualidad e irresponsabilidad hedonista que se cree innata a los naturales del país, como Alô, alô, Carnaval, de Adhemar Gozaga, 1935, y Carnaval Atlântida,1952, José Carlos Burle. Las estructuras narrativas de esas cintas develan tanto la tradición de la zarzuela y las operetas como de los espectáculos del music hall anglosajón.

Pero son las tentativas de industrialización de la producción de filmes en los tres países en que las proposiciones y argumentos de la modernidad occidental se establecen como referencias a la representación cinematográfica, aunque velados por el ropaje local de las producciones. Como se sabe, en México el proceso posrevolucionario fue en dirección al liberalismo y las producciones simbólicas reproducían, desde el decenio de 1920, una imaginación mexicanista que no congraciaba con la Revolución, a fin de cuentas un fenómeno violento que entre 1910 y 1920 dejó más de un millón de muertos. Entre los directores de cine que trascienden el periodo silencioso con el mismo acento sobre la iconografía nacional está Fernando de Fuentes (El prisionero 13, 1933, El compadre Mendoza, 1933, Vámonos con Pancho Villa, 1935, y Allá en el rancho grande, 1936). En todas esas cintas hay un punto de vista oblicuo sobre los fenómenos históricos que se relatan, como en la literatura lo tienen Mariano Azuela, Martín Luis Guzmán y Nelly Campobello. ${ }^{23}$

En México, los directores que surgieron a partir de la creación de la productora CLASA y de los Estudios Churubusco fueron los grandes articuladores de una representación suspicaz, que evocaba el nacionalismo y recurría al mobiliario de la Revolución sin apoyar sus postulados políticos

${ }^{23}$ Emilio García Riera, "El cine mexicano: una curiosa aventura”, en José Agustín Mahieu [org.], Panorama del cine iberoamericano, Madrid, Ediciones de Cultura Hispánica/Agencia Española de Cooperación Internacional, 1990, p. 13: “[...] en 1936 ocurrió un milagro. Al mismo De Fuentes que había dado con El compadre Mendoza y con Vámonos con Pancho Villa muestras de gran capacidad en el aprecio del fenómeno revolucionario (aun desde posiciones estrictamente pequeño burguesas) que fue un género muy frecuentado por el cine mexicano desde la época muda: el melodrama ranchero, claramente influido por una tradición teatral española. Así salió a la luz Allá en el Rancho Grande con toda su teoría de arrogancias y noblezas terratenientes, su nostalgia de la Arcadia bucólica y su implícito rechazo a la Reforma Agraria.” 
(reforma agraria, salud y educación, etc.). En sus estrategias representativas confluían las experiencias de los muralistas y de Sergei Eisenstein y Eduard Tissé en el país, que entre 1930-1931 filman escenas pintorescas de las tradiciones indígenas y de la geografía mexicana, con el resultado de una especie de mosaico étnico reunido en iQué viva México! También estaban los índices que Fred Zinnemann y Emilio Gómez Muriel dejan entrever en Redes, 1934, cuya historia sobre la comunidad de pescadores indígenas mexicanos tiene gran elaboración plástica (el film tuvo el apoyo de la Secretaría de Educación). Sin embargo, la gran constante de los esquemas de la representación fílmica es la tradición muralista nacional, de la cual los mismos Eisenstein, Tissé, Zinnemann y otros se nutrieron.

Además de las cintas de Fernando de Fuentes, de Sergei Eisenstein y de Emilio Gómez Muriel, otras obras paradigmáticas son Janitzio, 1935, de Carlos Navarro, y sobre todas las de la pareja Emilio Indio Fernández y Gabriel Figueroa, que elevan las figuras del nacionalismo, entre ellas el indígena idealizado, a una emotividad universal, que granjea el interés de los especialistas para el cine del país y consagraron un tipo de nacionalismo que denotaba un gran consenso de la representación. A despecho de que filmen gran cantidad de cintas, son las primeras, Flor silvestre, 1942/1943, María Candelaria, 1943, Río Escondido, 1947, Maclovia, 1948, ${ }^{24}$ las más emblemáticas, toda vez que combinan la sensibilidad para el oficio cinematográfico con los motivos nacionales y temas de ascendencia pseudorevolucionaria o indigenista. La fotografía de Gabriel Figueroa está inspirada en postulados muralistas, en los expresionistas y en las sugerencias dramáticas de Eduard Tissé y Paul Strand, colaboradores de Eisenstein y Zinneman, y logra una síntesis entre lo étnico y el expresionismo.

${ }^{24}$ Según los autores consultados, con gran experiencia en historia del cine, Flor Silvestre fue dirigida en 1942 y estrenada en 1943. María Candelaria estrenó en 1953, Río Escondido en 1947 y Maclovia en 1948. Aurelio de los Reyes, Medio siglo de cine mexicano (1896-1947), primera reimpresión, México, Trillas, 2002, pp. 198 y 199; Fernando del Moral González, "Cronología del cine mexicano (1896-1987)”, en Hojas de cine. Testimonios del nuevo cine latinoamericano, presentación de Emilio García Riera, SEP/UAM/Fundación Mexicana de Cineastas, 1988, v. II, pp. 282 y 283; Paranaguá, op. cit., pp. 112 y 113. 
El clímax del nacionalismo cultural cinematográfico es la obra del Indio Fernández como director y Gabriel Figueroa como fotógrafo. La resonancia es internacional. Luego de comienzos chovinistas (La isla de la pasión de 1941 y Soy puro mexicano de 1941, donde Pedro Armendáriz y el Chicote deshacen una conspiración del eje para invadirnos), el Indio se sumerge en tragedias monotemáticas: la Pareja es destruida por la fatalidad que es la incomprensión social, la Naturaleza es la esencia de la patria, la belleza sobrevive al crimen, quien se sacrifica por los demás comprende el mundo. Así descritas, las películas sólo desmerecen, son el resultado de un programa fatigoso [...] Contempladas ahora, desmienten cualquier negación apresurada. Flor silvestre con Pedro Armendáriz y Dolores del Río o Pueblerina (1948) con Columba Domínguez y Roberto Cañedo o La malquerida (1949) con Armendáriz y Dolores del Río o Víctimas del pecado (1950) con Ninón Sevilla, retiene una fuerza singular, no la de su proyección ideológica, sino la vehemencia lírica, el vigor, la excelencia visual de quien se siente develando el secreto de la nacionalidad al mostrar el destino irremediable de los amantes. ${ }^{25}$

En el mandato de Lázaro Cárdenas (1934-1940), para contrarrestar la escandalosa influencia extranjera, se trató de promover la producción y la exhibición nacional con un decreto que determinó que todas las salas de cine debían proyectar por lo menos un filme mexicano al mes. Pero en los gobiernos liberales de Manuel Ávila Camacho y Miguel Alemán (19401952), en plena Época de Oro, se propicia una radicalización de los motivos nacionalistas más ostensivos ${ }^{26} \mathrm{y}$, curiosamente, en el primer mandato, aumenta la ayuda norteamericana al cine mexicano que no se detiene pero se reduce mucho en los años posteriores.

En el periodo, se crean sindicatos y otras instituciones relacionadas con la dinámica capitalista y se constituye un verdadero sistema de industria cultural. En 1941 estrenan dos directores que son fundamentales para

25 Carlos Monsiváis, "Notas sobre la cultura mexicana en el siglo xx”, en Historia general de México, México, Colmex, 1977, t. IV, p. 444.

${ }^{26}$ Para la posición de los presidentes mexicanos en relación a la cultura, Héctor Aguilar Camín, En torno a la cultura nacional, México, SEP, 1982, hace un recuento de los discursos de los presidentes mexicanos en la toma de posesión, especialmente en lo que concierne a la cultura. 
la manutención de la industria. Julio Bracho, con ¡Ay, qué tiempos señor don Simón!, y el ya referido Emilio Indio Fernández, con La isla de la pasión. En 1942 se funda el Banco Cinematográfico, primer órgano de apoyo explícito del Estado a la producción nacional. Entonces, se firma una pléyade de movie stars: Dolores del Río, Jorge Negrete, María Félix, Pedro Armendáriz, Pedro Infante, Arturo de Córdoba, Cantinflas, por citar algunos que ya tenían experiencias exitosas en el cine mexicano y en el norteamericano.

El crecimiento numérico no siempre se tradujo en diversidad genérica, tampoco en calidad representativa del cine mexicano. Después de la exhibición con éxito del film de Fernando de Fuentes, en 1936, cuando se rodaron 25 películas, en 1937 son producidas 38 películas y, en 1938, 57, hasta llegar a un máximo de 124 en 1950, año que en Argentina se filmaron 56 y en Brasil nada más 20. ${ }^{27}$ En 1938, según Emilio García Riera, "se contaban más de veinte exaltaciones folklóricas”, en realidad epígonos de las incisivas producciones de Fernando de Fuentes y, entre 1931 y 1938, hay una proliferación de cintas con temas semejantes, por tanto no tardó tiempo para que la fórmula se agotara y que el ánimo de consenso de la industria cultural buscara otras combinaciones. ${ }^{28}$

El otro gran esfuerzo de creación de una industria del cine en América Latina fue hecho en Argentina, aunque no se compare a la envergadura de lo realizado en el cine mexicano y que los patrocinadores tuvieran, en principio, otros orígenes, italianos y alemanes. De cualquier manera, la inspiración para la empresa sudamericana fue el modelo de industrialización de Estados Unidos. En 1933 los empresarios de origen italiano Ángel Luis Men-

${ }^{27}$ Francisco Peredo Castro, Cine y propaganda para Latinoamérica. México y Estados Unidos en la encrucijada de los años 40, México, CCydel-unAm, 2004, p. 477.

${ }^{28}$ García Riera, op. cit., p. 70: “Durante la presidencia del general Cárdenas (1936-1940) se habían impulsado la independencia y 'mexicanidad' del cine, en una etapa que favoreció los proyectos de ambición artística y social. Janitzio (Carlos Navarro, 1935) inaugura el descubrimiento del indio como protagonista y su plasticidad. Afirmado desde 1940 en su desarrollo industrial, el cine conquista mercados y reconoce los premios en festivales. Aparte del Indio Fernández, se destacan obras aisladas, como el film Raíces, de Benito Alazraki, y sobre todo el notable documental Torero (1956), del español emigrado Carlos Velo.” 
tasti y Atilio Mentasti fundan la Argentina Sono Film. En 1937, con ayuda de representantes de la Pathé Nathan, de Francia, y principalmente de la Film Reich, de Alemania, comienzan a construir sus estudios en San Isidro, en las afueras de Buenos Aires. En 1950 Sono Film ya contaba con 30 mil metros cuadrados de instalaciones en un terreno de 50 mil metros, en donde podían realizarse varias películas al mismo tiempo. No obstante, hasta 1977, cuando cierra sus puertas, la empresa había producido 238 filmes y solamente entre 1940 y 1943 pudo estrenar una película al mes, su principal meta. Además de Sono Films, se fundó Aries Cinematográfica Argentina, productora de menor calado pero con un número importante de realizaciones en lo tres decenios de existencia, 90 films entre 1958-1989. No hay que olvidar la importancia de los Estudios San Miguel y Lumitón en la tentativa porteña, casi tan significativa como la de Sono Film.

Puede ilustrar las fuerzas motrices de la industria cultural en la región a mitad del siglo pasado el hecho de que uno de los mayores éxitos de Sono Film fuera la adaptación de una obra de teatro brasileña, Deus lhe pague, 1932, de Juracy Carmargo, (Dios se lo pague, Luis César Amadori, 1948). Ese melodrama traduce el clima de patetismo que vivía la política regional, potencializado por el romance imposible entre Perón y Evita de un lado y el tono grandilocuente de Getúlio Vargas por otro, por lo que se puede calificar muchas de las obras del periodo de producciones culturales populistas.

El modelo estatal de producción en el país fue otra alternativa que se materializó con el Instituto Nacional de Cine, creado en 1957, durante la junta militar instaurada después del exilio de Juan Domingo Perón en Paraguay. Ese órgano perdura hasta la actualidad y, paradójicamente, en un país en que las relaciones de los grupos que llegan al poder (en el siglo Xx, principalmente los militares) y los ciudadanos (civiles) no suelen ser armoniosas, se volvió uno de los principales apoyos a los directores, demostrando la necesidad de consensos y convergencias para la supervivencia de los artistas en la industria cultural.

En Argentina, la lucha por el mercado del cine a mitad del siglo pasado refleja un contencioso ideológico importante, que se desplegó en su totalidad durante la Segunda Guerra. Con muchos vínculos con empresas 
teutonas, la industria cinematográfica argentina, especialmente Sono filmes, con deudas con el Banco Germánico de Argentina y con la surtidora de películas vírgenes de aquel país, la alemana AGFA, fue blanco de diversas acciones del gobierno británico y norteamericano que, al final de la Guerra, se impusieron.

El auge del cine argentino se dio, como el mexicano, por intermedio del melodrama, ${ }^{29}$ un género coherente con la tradición de las radionovelas y del teatro de zarzuela (el género chico) español, y era inofensivo tanto a las susceptibilidades políticas nacionales como a las norteamericanas, además de coadyuvar directamente con el estilo de los musicales de Hollywood. Aparte de El Negro Ferreyra, el director más admirado por la crítica es Mario Soffici, quien filmó Viento del norte (1937), Los prisioneros de la tierra (1939) y Héroes sin gloria (1940), cuyas películas, sin embargo, no atañen fácilmente a ningún género específico.

En Brasil, como se ha dicho, las dimensiones del país hicieron que hubiera varios ciclos regionales de producción, calificados de surtos por Alex Viany. ${ }^{30}$ Sin embargo, los grandes centros urbanos, Río de Janeiro y São Paulo, resultaron ser los polos de producción fílmica y por tanto de reproducción de los esquemas de la imaginación de las élites locales, toda vez que estaban más actualizadas con los procesos económicos que envolvían la práctica de la industria cultural. El primer intento de formación de una base para la industria fílmica fue realizado en Río de Janeiro, al inicio del decenio de los treinta. Adhemar Gonzaga consiguió el dinero para comprar un terreno de 8 mil metros cuadrados en São Cristovão y allí fundó Cinédia que, al principio, se dedicó a filmes cuyas temáticas eran bastante serias y aun así tuvieron algún éxito de público y crítica, como Labios sem beijos, 1930, de Humberto Mauro (quien se había salido de Cataguases, Minas Gerais), Mulher, 1931, de Octavio Gabus Mendes, y el clásico Ganga bruta, 1933, de Humberto Mauro.

${ }^{29}$ Silvia Oroz, O cinema de lágrimas na América Latina, Río de Janeiro, Río Fundo, 1992.

${ }^{30}$ Alex Viany, op. cit., pp. 53-68. 
Se debe dejar claro que Brasil fue, de los tres países, el que tuvo menos producción en ese periodo y el que tuvo la industria cinematográfica menos articulada, y quizá por ello los directores tenían mayor libertad de filmación. Este país, en Latinoamérica, fue el único que tuvo grandes realizadores en la época silente (Alberto Cavalcanti, Humberto Mauro y Mário Peixoto, entre otros). En el caso de los dos primeros, pasaron a la época sonora sin perjuicio de la calidad. En México el caso más notable es el de Fernando de Fuentes.

Aunque Cinédia haya producido el primer clásico de la cinematografía local, Ganga Bruta, de pronto se vio conminada a combinar filmes de argumento reflexivo con otros temas, en dirección a las imágenes consensuadas. De esa manera, luego de una sociedad con el productor norteamericano Wallace Downey, produjo el primer gran éxito de taquilla en Brasil, Alô, alô carnaval, 1935, con Carmen Miranda. Cabe remarcar que el llamado musicarnavalesco no nació en Cinédia, pero si con Wallace Downey, quien trajo a Brasil los códigos del éxito de Hollywood. ${ }^{31}$ Luego de conceder sus estudios para la filmación de It's All True, film inacabado de Orson Welles sobre carnaval y pescadores brasileños, de 1942, los ejecutivos de Cinédia realizan otro rotundo éxito de género, el musical $O$ ebrio, 1946, de Gilda Abreu, cuyo título remite a una canción del popular cantante Vicente Celestino. Después de haber producido innumerables documentales y cinenoticiarios para el gobierno de Getúlio Vargas y aun sin acercarse a los grandes éxitos del pasado, Cinédia se mantuvo activo y en la actualidad es la productora más antigua de Brasil.

El otro intento de seguir el modelo del cine industrial en Brasil fue la productora Atlântida, fundada en Río de Janeiro en 1941 por José Carlos Burle, Paulo Burle, Moacyr Fenelon, Arnaldo Farias y Alinor Azevedo, con apoyo de la empresa de comunicaciones impresas Jornal do Brasil, que destinó una parte de sus instalaciones para la construcción de los pequeños estudios de la compañía. Luego de algunas tentativas de filmes serios, que

${ }^{31}$ La Enciclopédia do cinema brasileiro, organizada por Fernão Ramos y Luiz Felipe Miranda, São Paulo, Senac, 2000, trae información expuesta de manera didáctica sobre el periodo. 
contaron con la fotografía del virtuoso Edgard Brasil, uno de sus principales directores, Watson Macedo, en la segunda mitad del decenio de 1940, rueda películas carnavalescas y filma el género de Chanchada (comedia urbana): Não adianta chorar, Este mundo é um pandeiro, E o mundo se diverte, Carnaval no fogo y Aviso aos navegantes. Ya en los años de 1950, Carlos Manga sigue la tradición carnavalesca de chanchadas y realiza grandes éxitos con la pareja Grande Otelo y Oscarito, como Nen Sansão nem Dalila, Matar ou correr, O homem do Sputniik, Guerra ao samba, Quanto mais samba melhor, entre otros. En 1983 Atlântida deja de producir, aunque desde los años sesenta ya había vendido sus instalaciones.

La última tentativa de industrialización realizada en Brasil fue la Companhia Cinematográfica Vera Cruz, que tuvo una vida muy corta, 19491953, financiada por la burguesía de São Paulo, encabezada por Francisco Matarazzo Sobrinho y Franco Zampari, los mismos que crearon el Museu de Arte Moderna (MAM) y el Teatro Brasileiro de Comédia. En plena época de democracia política y liberalismo económico y social, luego de los quince años de la dictadura de Getúlio Vargas (1930-1945), Vera Cruz fue el intento más auspicioso de industrialización del cine en Brasil, que contrató equipos técnicos fuera del país, al punto de haber personas de 25 nacionalidades al mismo tiempo en la producción de su primera película, la indianista Caiçara, 1950, dirigida por el italiano Adolfo Celi.

Aunque la compañía se dedicara a producir filmes serios y adaptaciones literarias, como Sinhá Moça, 1952, Tom Payne, O Cangaceiro, 1953, Lima Barreto (premio a la mejor película de aventuras en el festival de Cannes), Floradas na serra, Luciano Salce, 1954, no dejó de producir películas cuyo éxito era seguro, como Tico-tico no fubá, Adolfo Celi, 1951, y Uma pulga na balança, Luciano Salce, 1953. En sus cuatro años de vida, Vera Cruz produjo 18 largometrajes, y dejó constancia de una calidad posible en la realización de filmes de género (abarcó el melodrama, film histórico, aventuras, policial, etc.). En los años que siguieron a su cierre, la marca de Vera Cruz quedó en filmes como O pagador de promesas, 1962, de Anselmo Duarte (única palma de oro a una película brasileña) y en los técnicos y los creativos de las agencias de publicidad de São Paulo y de 
las emisoras de televisión como Rede Globo, actual rectora de los sentidos y los sentimientos nacionales.

Recibido: 25 de enero, 2008. Aceptado: 19 de agosto, 2008.

\section{BIBLIOGRAFÍA}

Aguilar Camín, HÉctor, "Nociones presidenciales de cultura nacional.

De Álvaro Obregón a Gustavo Díaz Ordaz, 1920-1968’, en En torno a la cultura nacional, México, SEP, 1982, 272 pp.

Ayala Blanco, Jorge y María Luisa Amador, Cartelera cinematográfica 1930-1939 y 1940-1949, México, unAM, 1982, 458 pp.

Bernadet, Jean-Claude y Alcides Freire Ramos, Cinema e história do

Brasil, São Paulo, Contexto, 1994 [1988], 92 pp. (Colección Cinema e história do Brasil).

Brunner, José JoAquín, América Latina, cultura y modernidad, México,

Grijalbo/Conaculta, 1992, 402 pp. (Colección Claves de América Latina). García Riera, Emilio, Historia del cine mexicano, México, SEP, 1985, vol. 2, 356 pp.

"El cine mexicano: una curiosa aventura”, en José Agustín

Mahieu [coord.], en Panorama del Cine Iberoamericano, Madrid, Ediciones de Cultura Hispánica/Agencia Española de Cooperación Internacional, 1990, 368 pp.

Getino, Octavio, Cine argentino. Entre lo posible y lo deseable, Buenos Aires, Centro de Integración, Comunicación, Cultura y Sociedad, 1998, 243 pp. , Cine y televisión en América Latina. Producción y mercado, Santiago de Chile, LOM ediciones/Ediciones Ciccus, 1998, 390 pp. HABERMAs, JÜRGEN, “Modernidad, un proyecto incompleto”, en Nicolás Casullo [ed.], El debate modernidad-posmodernidad, Buenos Aires, Punto Sur, 1989 [1980], 134 pp. 
Herlinghaus, Herman, Renarración y descentramiento. Mapas alternativos de la imaginación en América Latina, Madrid, Iberoamericana/ Vervuert, 2004, 272 pp.

Martín-BArbero, Jesús, De los medios a las mediaciones. Comunicación, cultura y hegemonía, 2a ed., México, Gustavo Gilli, 1991, 300 pp. (Colección MassMedia).

Martín-BARBero, Jesús y GeRmÁn Rey, Los ejercicios del ver. Hegemonía audiovisual y ficción televisiva, Barcelona, Gedisa, 1999, 283 pp.

Mignolo, Walter, Historias locales/diseños globales. Colonialidad, conocimientos y pensamiento fronterizo, trad. de Juan María Madariaga y Cristina Vega Solís, Madrid, 2003, 365 pp.

MONSIVÁIS, CARLOS, "Cultura urbana y creación intelectual. El caso mexicano”, en Pablo González Casanova [coord.], Cultura y creación intelectual en América Latina, México, Siglo xxI, 1984, pp. 24-41. , "Notas sobre la cultura mexicana en el siglo Xx", en Historia general de México, México, Colmex, 1977, t. IV, pp. 256-301. Moral Gonzáles, Carlos Del, “Cronología del cine mexicano”, en Emilio García Riera [apres.], en Hojas de cine. Testimonios del nuevo cine latinoamericano, vol. II, México, SEP/Universidad Autónoma Metropolitana/Fundación Mexicana de Cineastas, 1988 (Colección Cultura Universitaria, Serie Ensayos), pp. 277-291.

Neto, José Teixeira Coelho, Dicionário de política cultural, São Paulo, Iluminuras, 1999 [1997], 572 pp.

Nubila, Domingo DI, La época de oro. Historia del cine argentino I, $4^{\mathrm{a}}$ ed., Buenos Aires, El Jilguero 1998, 317 pp.

Oroz, Silvia, O cinema de lágrimas na América Latina, Río de Janeiro, Río Fundo, 1992, 223 pp.

Ortiz, Renato, A moderna tradição brasileira, São Paulo, Brasiliense, 1995 [1988], 222 pp (Colección Tudo é história).

Paranaguá, Paulo Antonio, Tradición y modernidad en el cine de América Latina, Madrid, FCE, 2003, 300 pp. 
Paz-Soldán, Edmundo y Debra A. Castillo [eds.], Latin American

Literatura and Mass Media, Nueva York, Garland Publishing, 2001, 322 pp. Hispanic Issues.

Paz, Octavio, Los hijos del limo, Barcelona, Seix Barral, 1987 [1986], 208 pp. Peredo Castro, Francisco, Cine y propaganda para Latinoamérica. México y Estados Unidos en la encrucijada de los años 40, México, CcyDELUNAM, 2004, 509 pp.

RAMA, ÁNGEL, La ciudad letrada, Hanover, Ediciones del norte, 1984, 176 pp. , Las máscaras democráticas del modernismo, Montevideo, Fundación Ángel Rama, 1985, 198 pp.

Ramos, FERnão y Luiz Felipe Miranda [orgs.], Enciclopédia do cinema brasileiro, São Paulo, Senac, 2000, 582 pp.

Reyes, Aurelio de los, Medio siglo de cine mexicano (1896-1947), México, Trillas, 2002 (1987) (Colección Linterna Mágica), 225 pp.

Rocha, Glauber, Revisão crítica do cinema brasileiro, São Paulo, Cosac \& Naify, 2003 [1963], 113 pp.

SARLO, BEATRIZ, La imaginación técnica: sueños modernos de la cultura argentina, Buenos Aires, Nueva Visión, 1992, 153 pp. (Colección Nueva Visión).

Schnitman, Jorge, Film Industries in Latin America Dependency and Development, Noorwood, Nueva Jersey, Ablex Publishing Corporation, 1984, 280 pp.

SCHWARz, ROBERTO, “Nacional por subtração”, en Que horas são?, 2a ed., São Paulo, Companhia das Letras, 1997 [1987], 190 pp.

Viany, Alex, Introdução ao cinema brasileiro, Río de Janeiro, Revan, 1993, $148 \mathrm{pp}$.

Wortman, Ana [coord.], Pensar las clases medias. Consumos culturales y estilos de vida urbana en la Argentina en los noventa, Buenos Aires, La crujía, 1999, pp. 111-127.

Zubieta, Ana María [dir.], Cultura popular y cultura de masas. Conceptos, recorridos y polémicas, Buenos Aires, Paidós, 2000, 179 pp. 